\title{
Dynamic Herding Behavior in Pacific-Basin Markets: Evidence and Implications
}

\author{
Thomas C. Chiang \\ Drexel University, USA \\ Jiandong $\mathrm{Li}$ \\ Central University of Finance and Economics, China \\ Lin Tan \\ California State Polytechnic University, Pomona, USA \\ Edward Nelling* \\ Drexel University, USA
}

This study examines investor herding behavior in Pacific-Basin equity markets. Results indicate that the level of herding is time-varying, and is present in both rising and falling markets. It is positively related to stock market performance, but negatively related to market volatility. Herding estimates across markets are positively correlated, signifying comovement of herding behavior in the region. The findings suggest that tests for herding should consider its dynamic behavior. (JEL: G15, G14)

Keywords: herding behavior, stock return dispersion, kalman filter, nonlinearity, pacific-basin markets

\section{Introduction}

The term "herding" is often used in the finance literature to describe the correlation of investor behavior resulting from imitating other investors' trading activity. This correlation in activity may stem from

\footnotetext{
* We thank Vaalmikki Arjoon, Daniel F.S. Choi, and Duncan Shand for helpful comments and suggestions. Author Jiandong Li gratefully acknowledges support from the Chinese Ministry of Education (project approval \#:10YJC790129).
}

(Multinational Finance Journal, 2013, vol. 17, no. 3/4, pp. 165-200)

(C) Multinational Finance Society, a nonprofit corporation. All rights reserved. DOI: $10.17578 / 17-3 / 4-3$ 
informational cascades, as the observation of prior trades can be so informative that investors are willing to ignore their own current private information in trading. As a result, herding behavior leads a group of investors to move in the same direction, pushing stock prices further away from their economic fundamentals, causing price momentum and excess volatility (Bikhchandani, Hirshleifer, and Welch 1992; Nofsinger and Sias 1999). Academic researchers in behavioral finance identify herding as the collective irrationality of investors, leading to the mispricing of economic fundamentals (Shiller, 2005). ${ }^{1}$

To examine herding behavior, researchers commonly use a regression model to examine the cross-sectional dispersion of stock returns in response to changes in market conditions. Chang, Cheng, and Khorana (2000) find significant evidence of herding in South Korea and Taiwan, and partial evidence of herding in Japan, but no evidence in the US and Hong Kong. Zhou and Lai (2009) focus on the Hong Kong equity market, and document that herding activity there tends to be more prevalent in small stocks. They also find that investors are more likely to herd when selling rather than buying stocks, meaning that herding activity appears to be more pronounced in falling markets vis-à-vis rising markets. Demirer and Kutan (2006) investigate the Chinese market, and find no evidence of herding, suggesting that participants in the Chinese stock market make investment choices rationally. However, using a different data set, Tan et al. (2008) report that herding in Chinese stock markets occurs under both rising and falling market conditions. By analyzing industry-level data in a recent period, Chiang and Zheng (2010) document that herding exists in all Asian markets, but not in the US market. In summary, the evidence from international investors shows mixed results, and finds that herding behavior is most prevalent in emerging markets.

Although the aforementioned studies have provided insight regarding herding behavior in various aggregate markets, these empirical analyses have two limitations. First, their analysis is typically restricted to a single market, and no attempt is made to detect the interaction of herding behavior across national borders. This study is motivated by recent empirical evidence that greater co-movement by

1. This type of herding is referred to as intentional herding. In contrast, unintentional herding is mainly driven by fundamental (Bikhchandani and Sharma, 2001). It forms as investors receive correlated private information, share a similar educational background, and have equivalent analytical skills. As a result, they make similar investment decisions (see Hirshleifer, Subrahmanyam, and Titman, 1994). 
investors often takes place during periods of high volatility. Wermers (1999) examines herding in U.S. stocks by mutual funds and finds that it is stronger by growth-oriented funds and in small stocks. Boyer, Kumagai, and Yuan (2006), and Chiang, Jeon, and Li (2007) document that contagion effects spread financial risk across markets, and herding activity further exacerbates market crises. The recent sub-prime crisis in the US market attests to the global nature of crisis transmission. Thus, models of herding behavior that do not consider cross-market repercussions may be subject to misspecification errors. ${ }^{2}$

The second limitation of previous studies of herding is that they use a constant coefficient model. The estimated coefficients essentially reflect an average value of a functional relation over a specific sample period, and herding behavior is assumed to be unchanged throughout the period under investigation. When the market undergoes extreme stress, structural changes are likely to result, and constant coefficient estimators do not provide updated information to reveal market dynamics. A time-varying coefficient model is needed to capture the changing nature of herding behavior. Brown, Wei, and Wermers (2012) examine herding by mutual funds and find that herding effects have become more pronounced over time, as mutual fund ownership of stocks has increased.

To address the aforementioned empirical issues, this paper provides new evidence that helps to resolve the mixed findings of herding behavior in Pacific-Basin markets. More specifically, it presents a Kalman-filter-based model that allows the examination of the time-varying nature of herding behavior. The evidence shows that dynamic herding is significantly correlated with current stock returns, and is consistent with a positive-feedback trading hypothesis. However, the degree of herding becomes less pronounced as investors encounter uncertainty, regardless of whether this uncertainty arises from the domestic market, as measured by conditional variance, or from the global market, proxied by the implied volatility in the US market. The herding coefficients among different international investors are positively correlated, after controlling for a common global volatility factor.

The remainder of this paper is organized as follows. Section II

2. Chiang and Zheng (2010) investigate the cross-market correlation of stock return dispersions. However, correlation of return dispersions does not imply the correlation of herding coefficients. Thus, their analysis did not explicitly consider the interdependence of herding behavior across different national stock markets. 
presents the procedures used to test herding behavior in previous studies. Section III describes the data. Section IV reports empirical evidence of herding behavior using a constant coefficient model. Section V develops a time-varying coefficient model to estimate dynamic herding behavior. Section VI examines the factors that explain herding dynamics. Section VII presents additional evidence on herding by considering dynamic changes in state variables. Section VIII concludes.

\section{Detecting herding behavior by investors}

Conventional studies in the herding literature (Christie and Huang, 1995; Chang, Cheng, and Khorana, 2000; Hwang and Salmon, 2004; Gleason, Mathur, and Peterson, 2004; Demirer and Kutan, 2006) assume that investors act on common beliefs emerging from the market, or follow observed momentum. Thus, market conditions and information on prevailing collective movements form the basis for guiding investment decisions. Christie and Huang (1995) and Chang, Cheng, and Khorana (2000) argue that during normal periods, rational asset pricing models predict that the dispersion in returns will increase with the absolute value of the market return, since individual investors are trading with their own private information, which is diverse. However, during periods of extreme market movements, investors tend to suppress their own beliefs and are likely to follow the market consensus. Christie and Huang (1995) propose that herding can be detected by examining the statistical significance of individual stock-return dispersions in response to indicator variables that capture the time periods of extreme returns.

Chang, Cheng, and Khorana (2000) observe that the formation of herds is more likely to be present during periods of relatively large price swings, and suggest that variations in individuals' sentiments regarding investment activity may be reflected in the dispersions of the cross-sectional stock returns. To measure this phenomenon, they propose the measure of cross-sectional absolute deviation, $C S A D_{t}$, which is given by:

$$
C S A D_{t}=\frac{1}{N} \sum_{i=1}^{N}\left|R_{i, t}-R_{m, t}\right|
$$

where $C S A D_{t}$ is a measure of stock return dispersions, $N$ is the number 
of firms in the market or portfolio, and $R_{i, t}$ and $R_{m, t}$ are the value of a firm's realized return and an equally weighted realized return of firms on day $t$. To conduct a test for detecting herding activity, previous studies have used the following model:

$$
C S A D_{t}=\beta_{0}+\beta_{1}\left|R_{m, t}\right|+\beta_{2} R_{m, t}^{2}+\varepsilon_{t}
$$

where $C S A D_{t}$ is the measure of cross-sectional stock return dispersions, and $R_{m, t}$ is the return on the market index on day $t .{ }^{3}$ Both the absolute value and squared value of $R_{m, t}$ appear on the right-hand side of Equation (2). This is based on the rationale that under normal conditions, a linear positive relationship between the return dispersion and market return is anticipated.

However, during periods of relatively large price swings, in which market participants are more likely to follow the average consensus of all market opinions, the relation between CSAD and the average market return is more likely to be nonlinear and negative. A significantly negative coefficient $\beta_{2}$ indicates the presence of herding behavior, since it reflects the phenomenon that during periods of market stress, return dispersions decline. ${ }^{4}$ This coefficient, on the squared market return, captures the "curvature" of the relationship between the CSAD and the market return; a negative value represents "downward curvature" in the data, indicating that the $C S A D$ decreases with the square of the market return.

\section{Data}

The daily stock data employed in this study consist of individual firm

3. This specification has been used by Chang, Cheng, and Khorana (2000), Gleason, et al. (2004), Tan, et al. (2008), and Chiang and Zheng (2010), among others. Alternatively, the cross-sectional squared deviation, $C S S D_{\mathrm{t}}$, is also used in empirical tests of herding. However, as indicated by Duffee (2001), $C S S D_{\mathrm{t}}$ is more sensitive to the outliers. For this reason, this study uses the $C S A D_{t}$ measure.

4. This approach differs from the correlation analysis of contagion markets in the literature (Forbes and Rigobon, 2002). Note that comovements of stock returns cannot be interpreted as an evidence of herding. The methodology employed in this approach emphasizes the stock return dispersions in response to extreme market movements, rather than the stock market index comovements or integration among the Asian markets (Forbes and Rigobon, 2002; Chiang, Jeon, and Li, 2007; Yu, Fung, and Tam, 2010). 


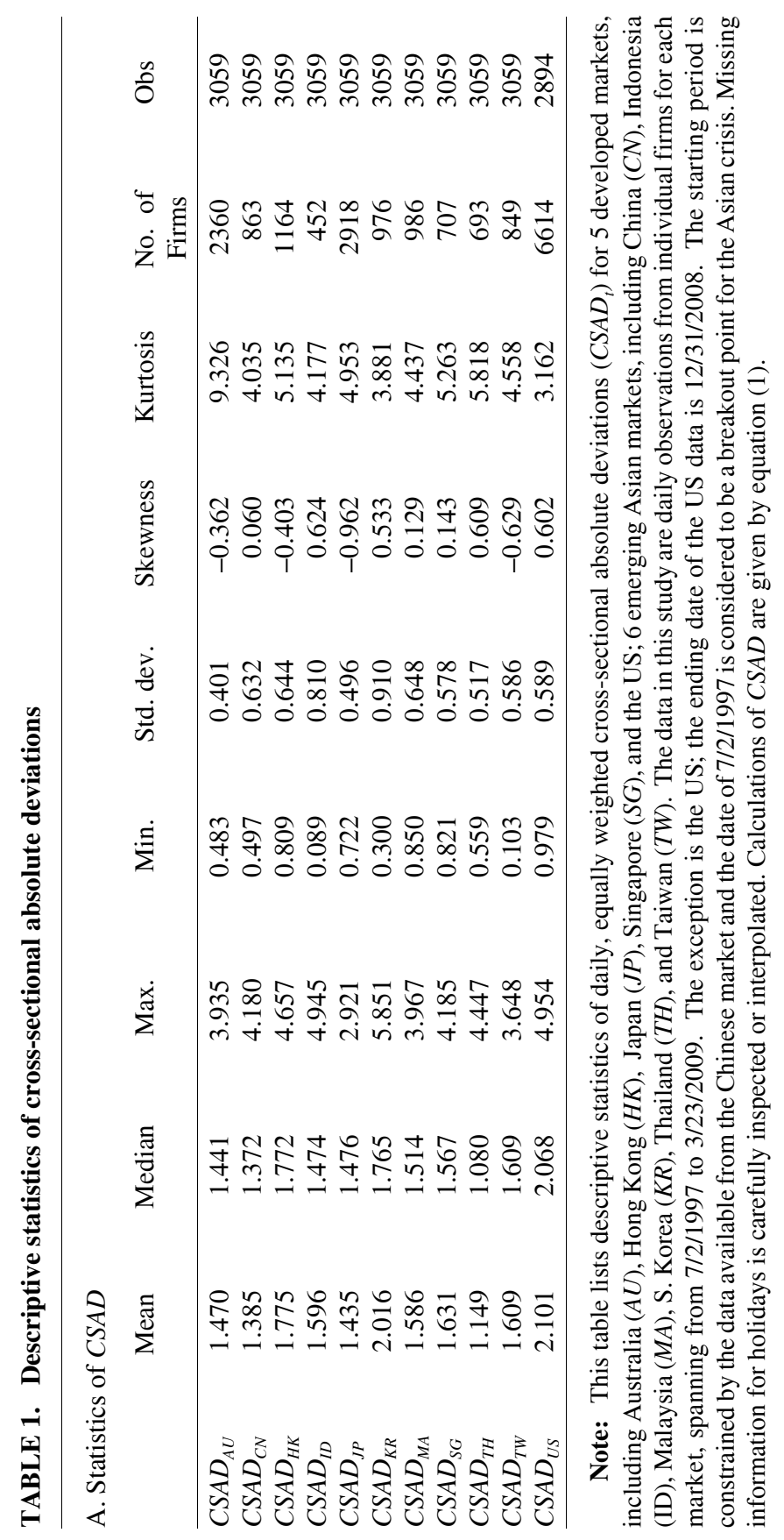




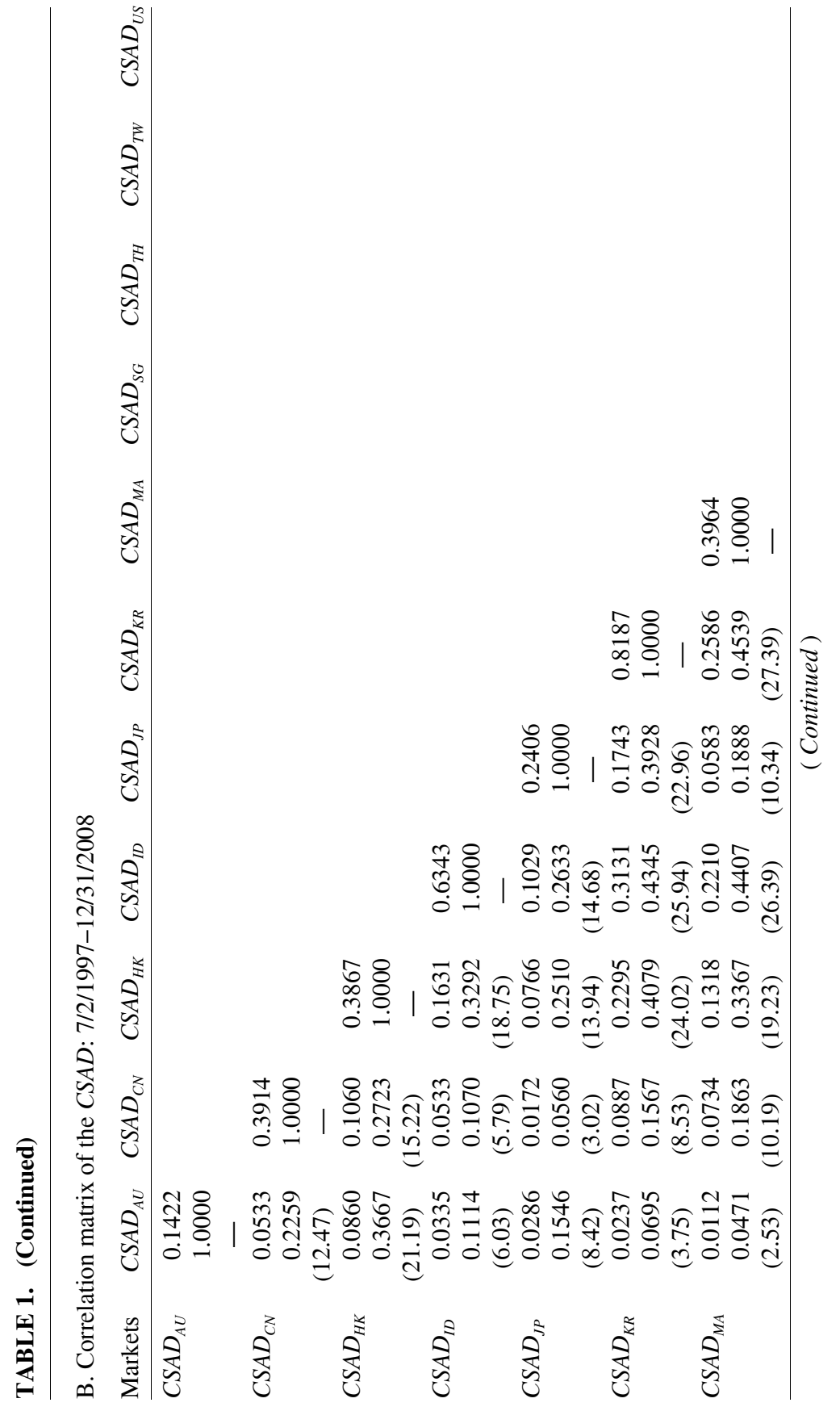




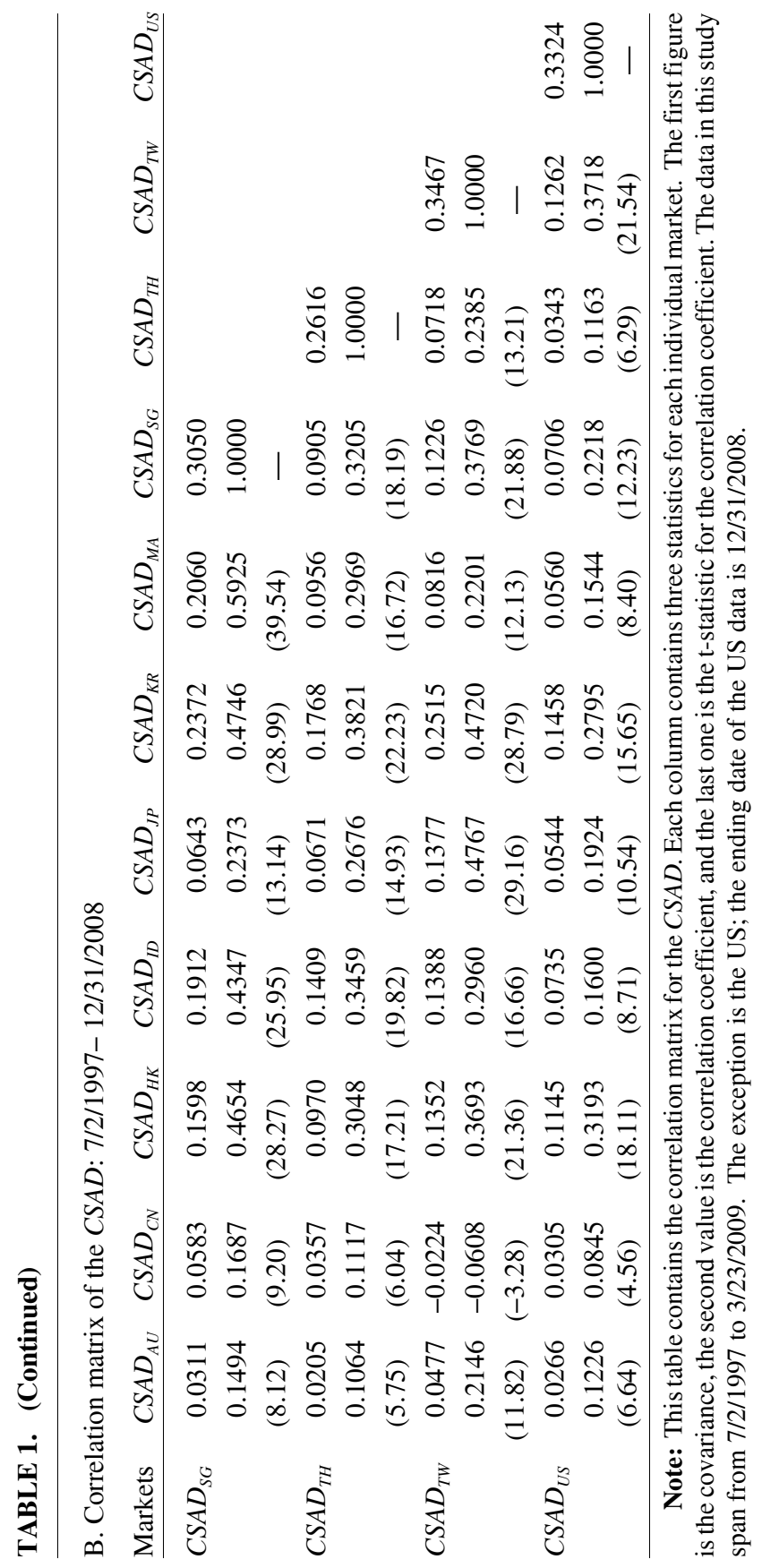




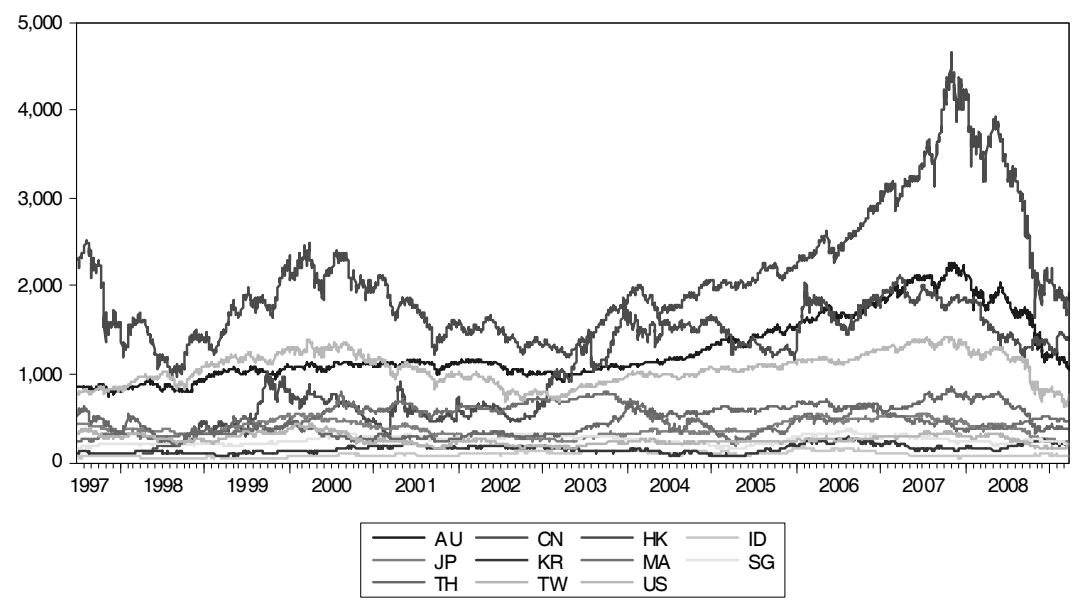

FIGURE 1.- Time series plots of aggregate market index based on Datastream data

stock prices and market price indices. The data cover five developed markets, including Australia (AU), Hong Kong (HK), Japan (JP), Singapore (SG), and the United States (US), and six emerging Asian markets, including China (CN), Indonesia (ID), Malaysia (MA), South Korea (KR), Thailand (TH), and Taiwan (TW). The sample period is from $7 / 2 / 1997$ through $3 / 23 / 2009$. The exception is the US, for which the ending date is $12 / 31 / 2008$. The choice of starting date is constrained by the availability of data for the Chinese market, and the rationale for using 7/2/1997 is that this date is considered to be the beginning of the Asian financial crisis. Missing information for holidays is carefully inspected or interpolated. The stock return is calculated as the change in the natural logarithm of stock price (index) times 100. With the exception of the US data, which is taken from the Compustat / CRSP files, all of the data are taken from Datastream International. The plots of stock index series are shown in figure 1.

Table 1 provides summary statistics of CSAD in individual company stock returns for different markets spanning the period from 7/2/1997 to $3 / 23 / 2009 .{ }^{5}$ The cross-section consists of eleven markets, with the number of companies in each market ranging from 452 (Indonesia) to

5. The exception is the US data, for which the date range is from $7 / 2 / 1997$ to 12/31/2008. 
6614 (the US). The US has the highest mean value of return dispersion, followed by South Korea and Hong Kong.

Panel B of table 1 presents the correlation matrix of CSADs among different markets. With the exception of the correlation for the CSAD between the China and Taiwan markets, which shows a negative sign, all of the other pairs of correlations are positive and highly significant. A special case is the Malaysian market, which has the highest correlation (0.593) with Singapore, and the lowest correlation (0.047) with Australia. ${ }^{6}$

\section{Evidence of herding behavior}

\section{A. Results of a constant-coefficient model}

Equation (2) is estimated using a consistent estimator (Newey-West, 1987). ${ }^{7}$ As stated earlier, a negative value on the coefficient of $R_{m, t}^{2}$ is interpreted as evidence of herding. The results in table 2 show that the estimated equation for each market has high explanatory power, as the adjusted R-squared ranges from 0.29 to 0.67 . Strikingly, all of the values of $\beta_{2}$ display a negative sign and are statistically significant at the $1 \%$ level. The results provide strong support for the existence of herding behavior in these markets. This finding is consistent with the multimarket analysis by Chiang and Zheng (2010). However, the evidence differs from the results reported by Chang et al. (2000), who find no evidence of herding in the US and HK markets, and only partial evidence of herding in the JP market. ${ }^{8}$ The result for the Chinese markets differs from the study reported by Demirer and Kutan (2006), who find no evidence of herding and conclude that participants in Chinese stock markets make rational investment choices.

6. The high correlation between Malaysia and Singapore may be attributable to their traditional ties in political constitution and economic system before Singapore's separation from Malaysia in 1965. In addition, these two countries are geographically connected.

7. Similar results are achieved by using a weighted least squares estimator.

8. The data are somewhat different from those of Chiang and Zheng (2010), in that they use industry-level data to construct $C S A D_{t}$, while this paper uses individual firm-level data to construct $C S A D_{t}$. The data also differ from the data used by Chang, Cheng, and Khorana (2000). They use daily firm returns over the period January 1963 to December 1997, for five markets: US, Hong Kong, Japan, South Korea, and Taiwan. In contrast, the data in this paper cover a more recent period, from 7/2/1997 to 3/23/2009, and cover an additional six markets. 
TABLE 2. Estimates of herding equation based on a constant coefficient model

\begin{tabular}{|c|c|c|c|c|}
\hline Markets & $C$ & $\left|R_{m, t}\right|$ & $R_{m, t}^{2}$ & $\bar{R}^{2}$ \\
\hline Australia & $\begin{array}{c}1.220 \\
(88.86)^{* * *}\end{array}$ & $\begin{array}{c}0.782 \\
(31.78)^{* * *}\end{array}$ & $\begin{array}{c}-0.060 \\
(-18.77)^{* * * *}\end{array}$ & 0.49 \\
\hline China & $\begin{array}{c}0.982 \\
(29.32)^{* * * *}\end{array}$ & $\begin{array}{c}0.417 \\
(15.24)^{* * * *}\end{array}$ & $\begin{array}{l}-0.030 \\
(-7.34)^{* * * *}\end{array}$ & 0.31 \\
\hline Hong Kong & $\begin{array}{c}1.283 \\
(61.72)^{* * * *}\end{array}$ & $\begin{array}{c}0.759 \\
(29.39)^{* * * *}\end{array}$ & $\begin{array}{c}-0.058 \\
(-10.66)^{* * *}\end{array}$ & 0.56 \\
\hline Indonesia & $\begin{array}{c}0.939 \\
(43.34)^{* * * *}\end{array}$ & $\begin{array}{c}1.032 \\
(36.36)^{* * * *}\end{array}$ & $\begin{array}{c}-0.084 \\
(-16.59)^{* * * *}\end{array}$ & 0.66 \\
\hline Japan & $\begin{array}{c}1.086 \\
(46.48)^{* * * *}\end{array}$ & $\begin{array}{c}0.588 \\
(16.97)^{* * * *}\end{array}$ & $\begin{array}{l}-0.057 \\
(-5.37)^{* * * *}\end{array}$ & 0.36 \\
\hline South Korea & $\begin{array}{c}1.224 \\
(40.54)^{* * *}\end{array}$ & $\begin{array}{c}0.816 \\
(23.79)^{* * *}\end{array}$ & $\begin{array}{c}-0.061 \\
(-10.10)^{* * *}\end{array}$ & 0.54 \\
\hline Malaysia & $\begin{array}{c}1.099 \\
(61.55)^{* * *}\end{array}$ & $\begin{array}{c}0.587 \\
(28.23)^{* * *}\end{array}$ & $\begin{array}{l}-0.031 \\
(-8.76)^{* * *}\end{array}$ & 0.67 \\
\hline Singapore & $\begin{array}{c}1.122 \\
(69.66)^{* * * *}\end{array}$ & $\begin{array}{c}0.737 \\
(39.79)^{* * * *}\end{array}$ & $\begin{array}{c}-0.059 \\
(-16.60) * * *\end{array}$ & 0.66 \\
\hline Thailand & $\begin{array}{c}0.716 \\
(46.71)^{* * *}\end{array}$ & $\begin{array}{c}0.896 \\
(26.53)^{* * *}\end{array}$ & $\begin{array}{l}-0.097 \\
(-9.33)^{* * *}\end{array}$ & 0.60 \\
\hline Taiwan & $\begin{array}{c}1.147 \\
(40.75)^{* * *}\end{array}$ & $\begin{array}{c}0.643 \\
(18.06)^{* * *}\end{array}$ & $\begin{array}{l}-0.084 \\
(-9.47) * * *\end{array}$ & 0.38 \\
\hline United States & $\begin{array}{c}1.769 \\
(54.57)^{* * *}\end{array}$ & $\begin{array}{c}0.470 \\
(14.33)^{* * *}\end{array}$ & $\begin{array}{l}-0.021 \\
(-4.56)^{* * *}\end{array}$ & 0.29 \\
\hline
\end{tabular}

Note: This table reports the regression results of CSAD. The estimated equation (2) is specified as: $C S A D_{t}=\beta_{0}+\beta_{1}\left|R_{m, t}\right|+\beta_{2} R_{m, t}^{2}+\varepsilon_{t} \quad$ where $C S A D_{t}$ is equally weighted cross-sectional absolute deviations; $R_{m, t}$ is the value of an equally weighted realized return of all firms' indexes on day $t$; and $R_{m, t}^{2}$ is the squared term of $R_{m, t}$. AU, CN, HK, ID, JP, KR, MA, SG, TH, TW, and the US denote the markets for Australia, China, Hong Kong, Indonesia, Japan, South Korea, Malaysia, Singapore, Thailand, Taiwan, and the United States, respectively. The data in this study are daily observations from individual firms for each market, spanning from $7 / 2 / 1997$ to $3 / 23 / 2009$. The exception is the US; the ending date of the US data is $12 / 31 / 2008 . \bar{R}^{2}$ is the adjusted R-squared. The numbers in parentheses are t-statistics. $* * *, * * *$ denotes that the coefficient is significant at the $1 \%, 5 \%$, and $10 \%$ levels, respectively.

\section{B. Asymmetry of herding behavior}

Recent empirical research (Bekaert and $\mathrm{Wu}, 2000$ ) recognizes the significance of asymmetric responses of volatility to different outcomes of market shocks. Tan, Chiang, Mason, and Nelling (2008) and Chiang provide evidence to substantiate asymmetric herding behavior under 
TABLE 3. Estimates of herding equation in rising and falling stock markets

A. Regression results when market rises $\left(R_{m, t}>0\right)$

\begin{tabular}{|c|c|c|c|c|}
\hline Markets & $C$ & $\left|R_{m, t}\right|$ & $R_{m, t}^{2}$ & $\bar{R}^{2}$ \\
\hline Australia & $\begin{array}{c}0.382 \\
(34.64)^{* * *}\end{array}$ & $\begin{array}{c}2.703 \\
(58.81)^{* * *}\end{array}$ & $\begin{array}{c}-0.388 \\
(-29.37)^{* * *}\end{array}$ & 0.55 \\
\hline China & $\begin{array}{c}0.291 \\
(25.05)^{* * * *}\end{array}$ & $\begin{array}{c}0.964 \\
(53.53)^{* * * *}\end{array}$ & $\begin{array}{c}-0.116 \\
(-30.72)^{* * *}\end{array}$ & 0.55 \\
\hline Hong Kong & $\begin{array}{c}0.358 \\
(29.49)^{* * *}\end{array}$ & $\begin{array}{c}2.089 \\
(70.42)^{* * * *}\end{array}$ & $\begin{array}{c}-0.311 \\
(-36.75)^{* * *}\end{array}$ & 0.69 \\
\hline Indonesia & $\begin{array}{c}0.291 \\
(27.59)^{* * * *}\end{array}$ & $\begin{array}{c}1.768 \\
(79.24)^{* * * *}\end{array}$ & $\begin{array}{c}-0.186 \\
(-41.23)^{* * *}\end{array}$ & 0.75 \\
\hline Japan & $\begin{array}{c}0.313 \\
(29.20)^{* * *}\end{array}$ & $\begin{array}{c}1.471 \\
(63.76)^{* * * *}\end{array}$ & $\begin{array}{c}-0.165 \\
(-27.40)^{* * *}\end{array}$ & 0.61 \\
\hline South Korea & $\begin{array}{c}0.384 \\
(27.77)^{* * *}\end{array}$ & $\begin{array}{c}1.575 \\
(66.90)^{* * * *}\end{array}$ & $\begin{array}{c}-0.159 \\
(-34.66)^{* * *}\end{array}$ & 0.68 \\
\hline Malaysia & $\begin{array}{c}0.344 \\
(31.86)^{* * * *}\end{array}$ & $\begin{array}{c}1.054 \\
(72.96)^{* * * *}\end{array}$ & $\begin{array}{c}-0.061 \\
(-40.93)^{* * *}\end{array}$ & 0.68 \\
\hline Singapore & $\begin{array}{c}0.302 \\
(29.09)^{* * * *}\end{array}$ & $\begin{array}{c}1.612 \\
(74.09)^{* * * *}\end{array}$ & $\begin{array}{c}-0.189 \\
(-38.25)^{* * *}\end{array}$ & 0.72 \\
\hline Thailand & $\begin{array}{c}0.215 \\
(28.69)^{* * * *}\end{array}$ & $\begin{array}{c}1.532 \\
(75.57)^{* * * *}\end{array}$ & $\begin{array}{c}-0.207 \\
(-35.49)^{* * *}\end{array}$ & 0.71 \\
\hline Taiwan & $\begin{array}{c}0.307 \\
(26.28)^{* * * *}\end{array}$ & $\begin{array}{c}1.547 \\
(65.90)^{* * * *}\end{array}$ & $\begin{array}{c}-0.248 \\
(-38.53)^{* * *}\end{array}$ & 0.65 \\
\hline United States & $\begin{array}{c}0.496 \\
(29.69)^{* * *}\end{array}$ & $\begin{array}{c}1.981 \\
(56.19)^{* * *}\end{array}$ & $\begin{array}{c}-0.223 \\
(-25.79)^{* * * *}\end{array}$ & 0.57 \\
\hline \multicolumn{5}{|c|}{ B. Regression results when market declines $\left(R_{m, t}<0\right)$} \\
\hline Australia & $\begin{array}{c}0.409 \\
(36.30)^{* * * *}\end{array}$ & $\begin{array}{c}1.814 \\
(57.07) * * *\end{array}$ & $\begin{array}{c}-0.172 \\
(-32.62)^{* * *}\end{array}$ & 0.54 \\
\hline China & $\begin{array}{c}0.232 \\
(21.57)^{* * * *}\end{array}$ & $\begin{array}{c}1.065 \\
(61.89)^{* * * *}\end{array}$ & $\begin{array}{c}-0.105 \\
(-33.14)^{* * *}\end{array}$ & 0.67 \\
\hline Hong Kong & $\begin{array}{c}0.388 \\
(31.59)^{* * * *}\end{array}$ & $\begin{array}{c}1.433 \\
(67.80)^{* * * *}\end{array}$ & $\begin{array}{c}-0.128 \\
(-37.49)^{* * *}\end{array}$ & 0.65 \\
\hline Indonesia & $\begin{array}{c}0.283 \\
(26.93)^{* * * *}\end{array}$ & $\begin{array}{c}1.638 \\
(78.56) * * *\end{array}$ & $\begin{array}{c}-0.170 \\
(-38.17)^{* * *}\end{array}$ & 0.75 \\
\hline Japan & $\begin{array}{c}0.281 \\
(26.73)^{* * * *}\end{array}$ & $\begin{array}{c}1.562 \\
(64.55)^{* * * *}\end{array}$ & $\begin{array}{c}-0.236 \\
(-36.34)^{* * *}\end{array}$ & 0.64 \\
\hline South Korea & $\begin{array}{c}0.356 \\
(25.73)^{* * * *}\end{array}$ & $\begin{array}{c}1.390 \\
(69.72)^{* * * *}\end{array}$ & $\begin{array}{c}-0.119 \\
(-39.37)^{* * *}\end{array}$ & 0.69 \\
\hline Malaysia & $\begin{array}{c}0.397 \\
(36.47)^{* * *}\end{array}$ & $\begin{array}{c}1.066 \\
(71.66)^{* * * *}\end{array}$ & $\begin{array}{c}-0.074 \\
(-40.40)^{* * *}\end{array}$ & 0.67 \\
\hline
\end{tabular}

( Continued) 
TABLE 3. (Continued)

\begin{tabular}{lcccc}
\hline Markets & $C$ & $\left|R_{m, t}\right|$ & $R_{m, t}^{2}$ & $\bar{R}^{2}$ \\
\hline Singapore & 0.318 & 1.606 & -0.196 & 0.73 \\
& $(30.13)^{* * *}$ & $(75.66)^{* * *}$ & $(-39.71)^{* * *}$ & \\
Thailand & 0.212 & 1.588 & -0.213 & 0.73 \\
& $(26.72)^{* * *}$ & $(80.62)^{* * *}$ & $(-40.48)^{* * *}$ & \\
Taiwan & 0.294 & 1.455 & -0.215 & 0.67 \\
& $(25.47)^{* * *}$ & $(64.41)^{* * *}$ & $(-37.21)^{* * *}$ & \\
United States & 0.449 & 1.771 & -0.201 & 0.58 \\
& $(27.39)^{* * *}$ & $(56.32)^{* * *}$ & $(-30.64)^{* * *}$ & \\
\hline
\end{tabular}

C. Wald test $H_{0}: \beta_{21}-\beta_{22}=0$

\begin{tabular}{|c|c|c|}
\hline & $\beta_{21}-\beta_{22}$ & Chi-square statistics \\
\hline Australia & -0.216 & $(229.60)^{* * *}$ \\
\hline China & -0.011 & $(4.59)^{* *}$ \\
\hline Hong Kong & -0.183 & $(402.30)^{* * *}$ \\
\hline Indonesia & -0.017 & $(6.79)^{* * *}$ \\
\hline Japan & 0.071 & $(63.85)^{* * *}$ \\
\hline South Korea & -0.040 & $(53.14)^{* * *}$ \\
\hline Malaysia & 0.012 & $(26.87)^{* * *}$ \\
\hline Singapore & 0.007 & $(1.09)$ \\
\hline Thailand & 0.005 & $(0.48)$ \\
\hline Taiwan & -0.032 & $(13.74)^{* * *}$ \\
\hline United States & -0.022 & $(4.13)^{* *}$ \\
\hline
\end{tabular}

Note: This table reports the regressions results of the herding equation for the United States and the Pacific-Basin stock markets in rising and falling markets. The estimated equations are:

$$
\begin{aligned}
& C S A D_{t}^{+}=\beta_{01}+\beta_{11}\left|R_{m, t}^{+}\right|+\beta_{21}\left(R_{m, t}^{+}\right)^{2}+\varepsilon_{1, t} \text { if } R_{m, t}>0 \\
& C S A D_{t}^{-}=\beta_{02}+\beta_{12}\left|R_{m, t}^{-}\right|+\beta_{22}\left(R_{m, t}^{-}\right)^{2}+\varepsilon_{2, t} \text { if } R_{m, t}<0
\end{aligned}
$$

where $R_{m, t}^{+}\left(R_{m, t}^{-}\right)$is the equally weighted market return during period $\mathrm{t}$ when the market is up, denoted by "+" (down, which is denoted by "_"). Panel A reports the estimates in rising markets, Panel $\mathrm{B}$, for down markets, and Panel $\mathrm{C}$ reports the test statistics for the difference in herding coefficients between the two regimes. The sample period is from $7 / 2 / 1997$ to $3 / 23 / 2009$. The US data are from $7 / 2 / 1997$ to $12 / 31 / 2008$ Numbers in parentheses are t-statistics based on Newey-West (1987) consistent standard errors. ***, **, and $*$ denote statistical significance at the $1 \%, 5 \%$, and $10 \%$ levels, respectively.

different market conditions. Chiang, Chen, and So (2007) find asymmetric effects of news on stock returns and volatility in 
international markets. To examine whether herding behavior presents an asymmetric reaction on days when the market is rising vis-à-vis days when the market is falling, Equation (2) is rewritten conditional on the following two regimes:

$$
\begin{aligned}
& C S A D_{t}^{+}=\beta_{01}+\beta_{11}\left|R_{m, t}^{+}\right|+\beta_{21}\left(R_{m, t}^{+}\right)^{2}+\varepsilon_{1, t}, \text { if } R_{m, t}>0 \\
& C S A D_{t}^{-}=\beta_{02}+\beta_{12}\left|R_{m, t}^{-}\right|+\beta_{22}\left(R_{m, t}^{-}\right)^{2}+\varepsilon_{2, t}, \text { if } R_{m, t}<0
\end{aligned}
$$

where $R_{m, t}^{+}\left(R_{m, t}^{-}\right)$is the equally weighted market return during period t when the market is rising, denoted by " + " (falling, which is denoted by "-_), and the second subscripts 1 and 2 on the $\beta$ coefficient identify rising and falling regimes. Table 3 presents the estimated herding coefficients under rising (Panel A) and falling (Panel B) market conditions. Results indicate a statistically significant negative sign for the herding coefficient, regardless of whether the market is rising or falling, implying that herding occurs in either regime.

The asymmetry of herding coefficients between rising and falling markets is examined using a Wald test, which subtracts the coefficient on the falling markets from the coefficient on the rising markets, $\left(\beta_{21}-\right.$ $\beta_{22}$ ). The results are reported in Panel $\mathrm{C}$ of table 3 , and indicate that asymmetry is significant in 9 out of 11 markets. The exceptions are Singapore and Thailand. In the majority of markets, the herding effect appears to be stronger during rising markets than during falling markets.

One possible explanation for an asymmetry in herding between rising and falling markets is the flow of positive and negative information. For example, if analysts tend to issue buy recommendations more actively than sell recommendations, and investors act on the recommendations, we would observe more herding in rising markets. Another possibility is that investors believe that the government will intervene when markets decline significantly, and are thus less likely to herd in falling markets.

McQueen, Pinegar, and Thorley (1996) document that, in down markets, contemporaneous small stock betas increase. This would result in the CSAD decreasing, since increased betas across many stocks would lead to increased pairwise stock correlations. This argument implies that herding is greater in down markets. The test results in Panel $\mathrm{C}$ of table 3 do not support this view for most markets, as herding is 
stronger when the market is rising. One potential explanation is that investors may pay more attention to large firms in rising markets as they engage in herding activity.

Another source of asymmetry in herding under different market conditions could result from portfolio managers responding to investor behavior during extreme market events. Specifically, mutual fund managers generally need to sell securities to raise cash when they face significant redemption requests. If redemption requests are more prevalent during market declines, herding may result. In contrast, strong inflows into mutual funds do not necessarily result in widespread buying by fund managers, because they can be more patient when implying buying programs. Since our results find greater herding during rising markets, the fund flow explanation is not likely to be the driving force. Alternatively, flows could play a role, but the result is not observable if mutual funds represent a relatively small percentage of security holdings in the markets examined.

\section{Analysis of time-varying herding behavior}

\section{A. The model}

The conventional estimation using a constant-coefficient regression model in the above analysis provides evidence on the average relation over time between stock return dispersions and squared market returns. In other words, the estimated result for detecting herding is essentially static in nature. The dynamic behavior of herding activity is captured using a Kalman-filter-based model (Kalman, 1960), which is expressed as:

$$
\begin{gathered}
C S A D_{t}=\beta_{0, t}+\beta_{1, t}\left|R_{m, t}\right|+\beta_{2, t} R_{m, t}^{2}+\varepsilon_{t} \\
\beta_{i, t}=\beta_{i, t-1}+v_{i, t}, \quad v_{i, t} \sim N\left(0, \sigma_{v, i}^{2}\right), \text { where } i=0,1 \text {, and } 2
\end{gathered}
$$

Equation (4) is the measurement equation and $\left[\beta_{0, t}, \beta_{1, t}, \beta_{2, t}\right]$ ' is a vector of state variables. Equation (5) is called a transition equation, and the state variables are assumed to evolve with a random walk process. A special feature of this model is that the coefficients are time-varyin 
and can be obtained by using the Kalman filter procedure. ${ }^{9}$

\section{B. Estimates of time-varying herding behavior}

Figure 2 presents the plots of the time series estimates of herding coefficients for 11 markets based on the state-space model. The herding series are time-varying and appear to be stationary. Most of the markets exhibit coefficients around the -0.2 level. The exception is the herding coefficient in the US market, which most of the time lies in the positive region, showing an absence of herding activity. This finding is in contrast to the result based on the constant-coefficient regression estimation of herding in the US market, indicating a misleading statistical inference.

Additional insight regarding the time-varying nature of herding is obtained from summary statistics and the correlation matrix of the herding coefficients in tables 4 and 5, respectively. Several interesting points emerge. The mean and median values for all of the non-US markets are negative. These values, along with consistent sign of skewness statistics, suggest that herding activity is widely present in these regions. This finding is consistent with the evidence reported in table 2, except for the US market.

Note that the constant coefficient estimated using OLS is not an average of the time-varying coefficients, as noted by Garbade and Wachtel (1978). For instance, the average slope coefficients for AU, HK, and JP are $-0.259,-0.296$, and -0.267 from the time-varying coefficient model, compared with $-0.060,-0.058$, and -0.057 from the constant coefficient model, respectively. More dramatically, in the US market, the mean value is 0.04 in the time-varying coefficient model, versus -0.021 in the constant coefficient estimator. The time-varying coefficient evidence is consistent with the earlier finding for rejecting the null hypothesis of equal coefficients during rising and falling markets, as indicated by the Wald test. The evidence in table 4, in conjunction with the time series plots of figure 2, clearly indicates that herding activity varies over time, suggesting that using a constant coefficient approach cannot accurately test for herding behavior.

9. One can substitute equation (5) into equation (4) to obtain an expanded regression. Maddala and Kim (2002) first use an OLS method to obtain the estimated variances of $\varepsilon$ and $v$. Then, they apply GLS in the estimation. Harvey (1990), Hamilton (1994), and Tsay (2005) provide a detailed description of the Kalman filter estimation. Yu, Fung, and Tam (2010) use this method to analyze the Asia-equity market indices. 


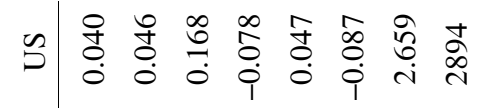

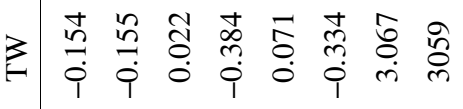

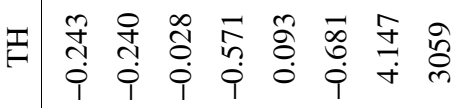

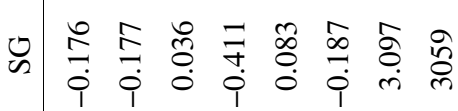

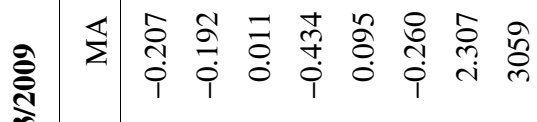

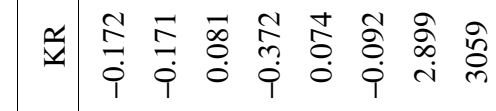

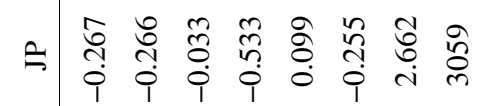

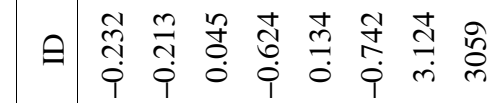

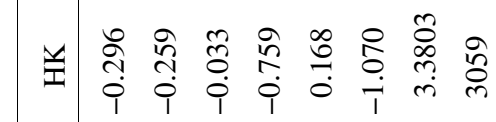

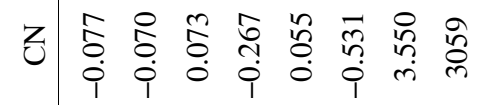

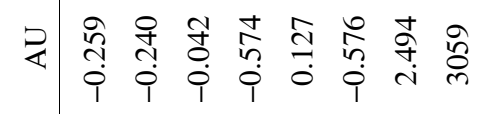

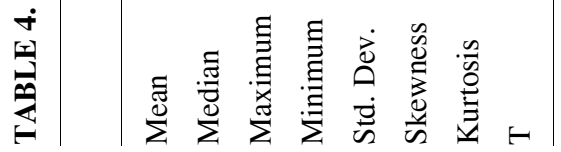




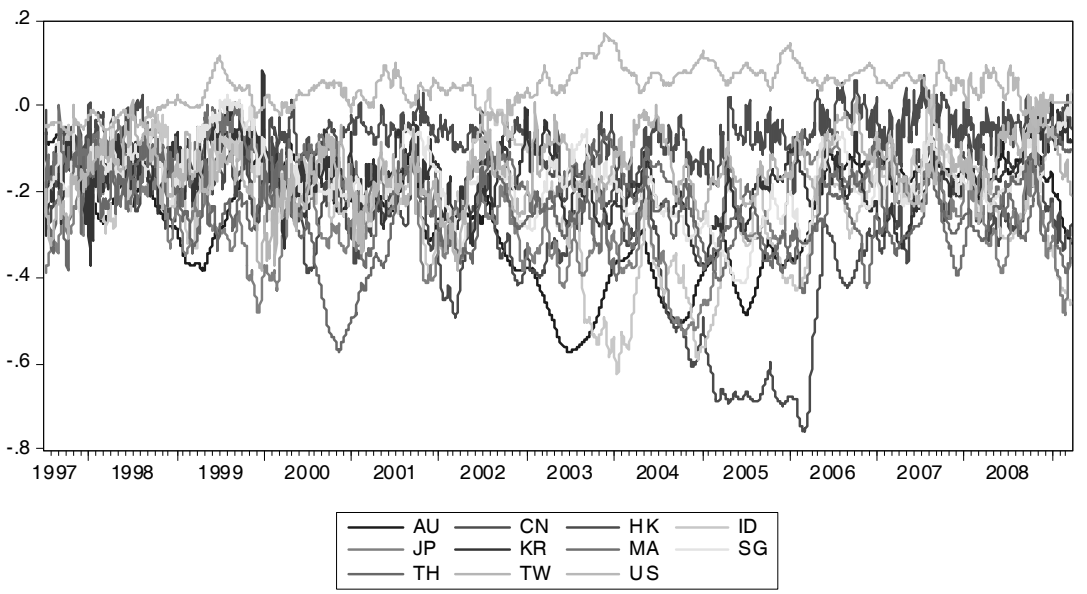

FIGURE 2.- Time series plots of herding coefficients for 11 markets

Statistics of maximum value for some markets, such as AU, HK, JP, and $\mathrm{TH}$, exhibit a negative sign, meaning that herding behavior is consistently and unambiguously present throughout the sample period under investigation. The max-min range and standard deviation of the herding series indicate that $\mathrm{HK}, \mathrm{ID}, \mathrm{AU}$, and TH exhibit much higher variations than other markets.

Table 5 reports the correlation matrix of herding coefficients. It is notable that, in general, herding in all the markets in the Pacific-Basin is highly correlated in a positive direction. ${ }^{10}$ Except for Taiwan, herding in all countries is negatively correlated with herding in the US market. The evidence is consistent with the earlier finding by Chiang, Jeon, and $\mathrm{Li}$ (2007) in their study of the Asian crisis. However, the results of this study suggest that the co-movement of herding extends beyond the crisis period. Consistently, the negative correlations of the herding series for most Pacific-Basin markets with the US market indicate a lack of co-movement of herding with the US market, although the stock return dispersions are positively correlated, as shown in table 1 . Note that

10. There are a few cases that show a negative correlation with the series for Indonesian and Malaysian markets. 


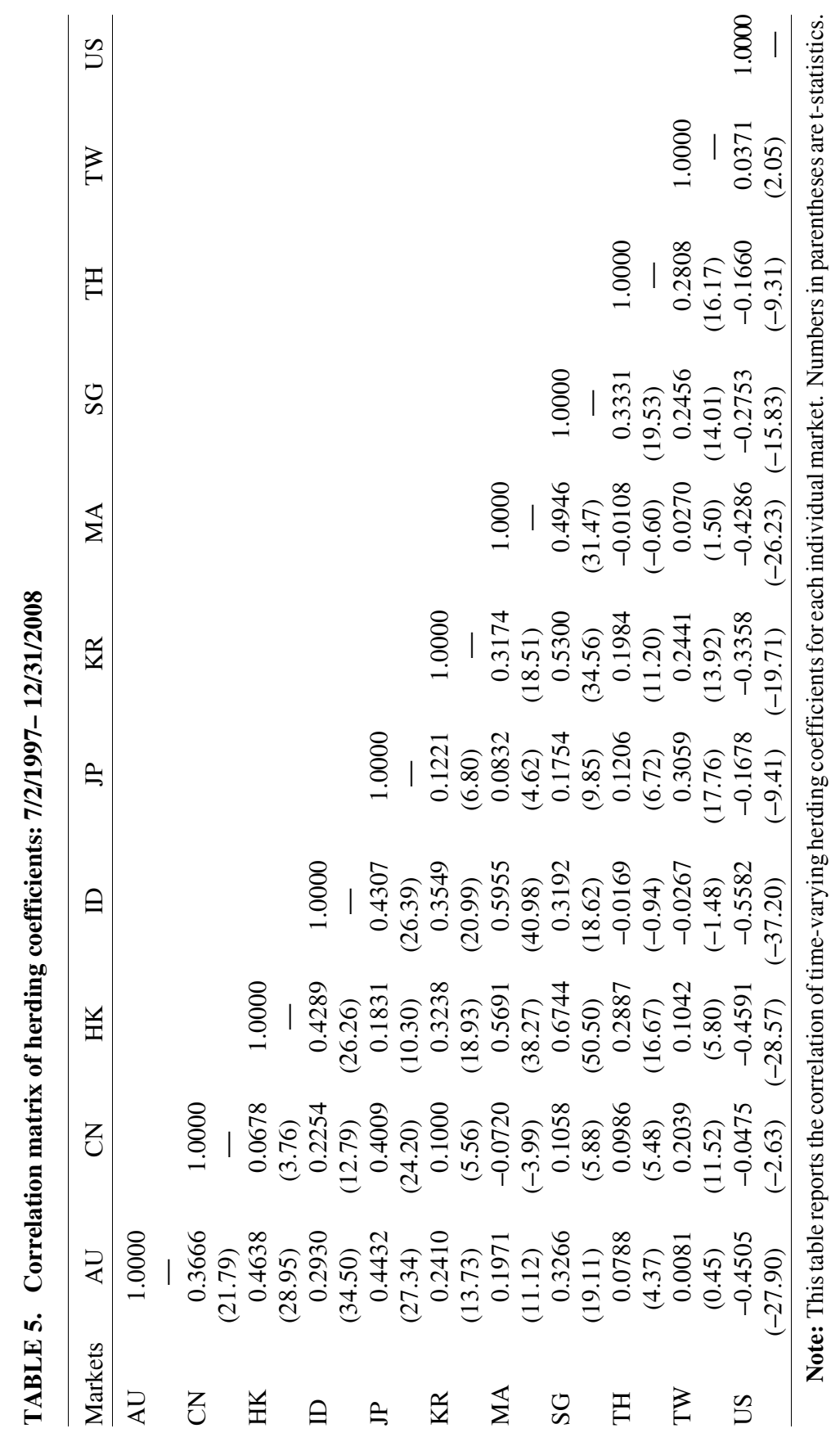


correlation in stock return dispersions does not imply correlation in herding. The former reflects the relation of cross-sectional return-dispersions between countries, or correlation of market risk (Chiang and Zheng, 2010), while correlation of herding behavior (denoted by the $\beta_{2, t}$ coefficient) reflects how the return dispersions commonly react to market conditions in the two countries.

Evidence presented in this section has important implications for estimating the relation between stock return dispersions and extreme market conditions. First, the time-varying nature of the herding coefficient is likely to be endogenously correlated with state variables that reflect specific market conditions. Second, herding coefficients are positively correlated across different Pacific-Basin markets, but not with the U.S. market. These findings suggest that the estimated coefficient based on equation (2) can result in biased inferences.

\section{Determinants of herding dynamics}

\section{A. Domestic market factors}

The results noted above indicate that herding behavior is time-varying for a group of markets in the Pacific Basin. The next job is to identify its determinants, which is addressed by the hypotheses below.

(i) Stock performance hypothesis: Herding activity is perceived to be correlated with stock market performance. Research demonstrates that investors react to stock prices (Grinblatt, Titman, and Wermers, 1995). Evidence (DeLong et al. 1990; Sentana and Wadhwani, 1992) suggests that positive feedback traders buy stocks in a rising market and sell stocks in a falling market, while negative feedback traders follow an investment strategy of "buy low and sell high." The lack of an a priori reason to believe which type of feedback-trading strategy herding investors intend to follow, allows for either a positive or negative sign on the coefficient on the stock market return.

(ii) Volatility hypothesis: Herding behavior is likely to be related to stock market volatility. This hypothesis is associated with the fundamental characteristics of herding formation that occur during periods of market stress. The empirical literature (Butler and 
Joaquin, 2002; Forbes and Rigobon, 2002; Corsetti et al., 2005) shows that cross-market correlations rise in periods of high volatility. These studies raise the issue of whether herding activity is influenced by stock return volatility. Following the conventional approach, the conditional stock return variance is modeled as an asymmetric GARCH(1,1)-type process.

The above hypotheses are examined with the following regression model:

$$
\operatorname{Herd}_{t}=\varphi_{0}+\varphi_{1} R_{m, t}+\varphi_{2} \hat{\sigma}_{t}^{2}+\varepsilon_{t}
$$

where the dependent variable, Herd $_{t}$, is the estimated herding coefficient on day $t, \beta_{2, t}$, which is derived from the state-space model in equation (4); $R_{m, t}$ is stock market return, $\hat{\sigma}_{t}^{2}$ is the conditional variance of stock returns based on asymmetric $\operatorname{GARCH}(1,1)$ process for each market, $\varphi_{\mathrm{i}}(i=0,1,2)$ denotes constant parameters, and $\varepsilon_{\mathrm{t}}$ is an error term. ${ }^{11}$

Table 6 reports consistent estimates for each hypothesis involving univariate and multivariate regressions. The sample period spanning from January 4, 1999 to March 23, 2009 is used to avoid possible disturbance due to the Asian crisis. Several empirical findings are worth noting. First, the estimated coefficients for stock market returns show a negative sign, and the majority of the coefficients are statistically significant. ${ }^{12}$ Since the herding coefficient, $\beta_{2}$, is negative, the inverse relation between the herding coefficient and stock returns is consistent with a market phenomenon that when stock returns rise, the observed herding measure increases. One interpretation is that when stock markets experience positive returns, investors tend to discard their own private beliefs and move along with market consensus, and thus herding

11. As a robustness check, an alternative measure of stock returns was constructed using recent momentum based on the past five days' moving average return for an individual stock market, i.e., (1/5) $\sum_{s=1}^{5} R_{m, t-s}$. The results are similar to those reported in table 6 .

12. Less clear are the cases for Malaysia and Singapore. Note that the Malaysian financial system is mainly governed by Shariah law. The IMF Survey Magazine (2007) reports that Shariah-compliant stocks comprise about 86 percent of domestic stock exchange. The Survey indicates that the Ninth Malaysia Plan allocates 200 billion Malaysian ringgit for developmental projects and 20 billion for private finance initiatives. The system in Singapore is highly tied to Malaysia as we observe in footnote 5. 


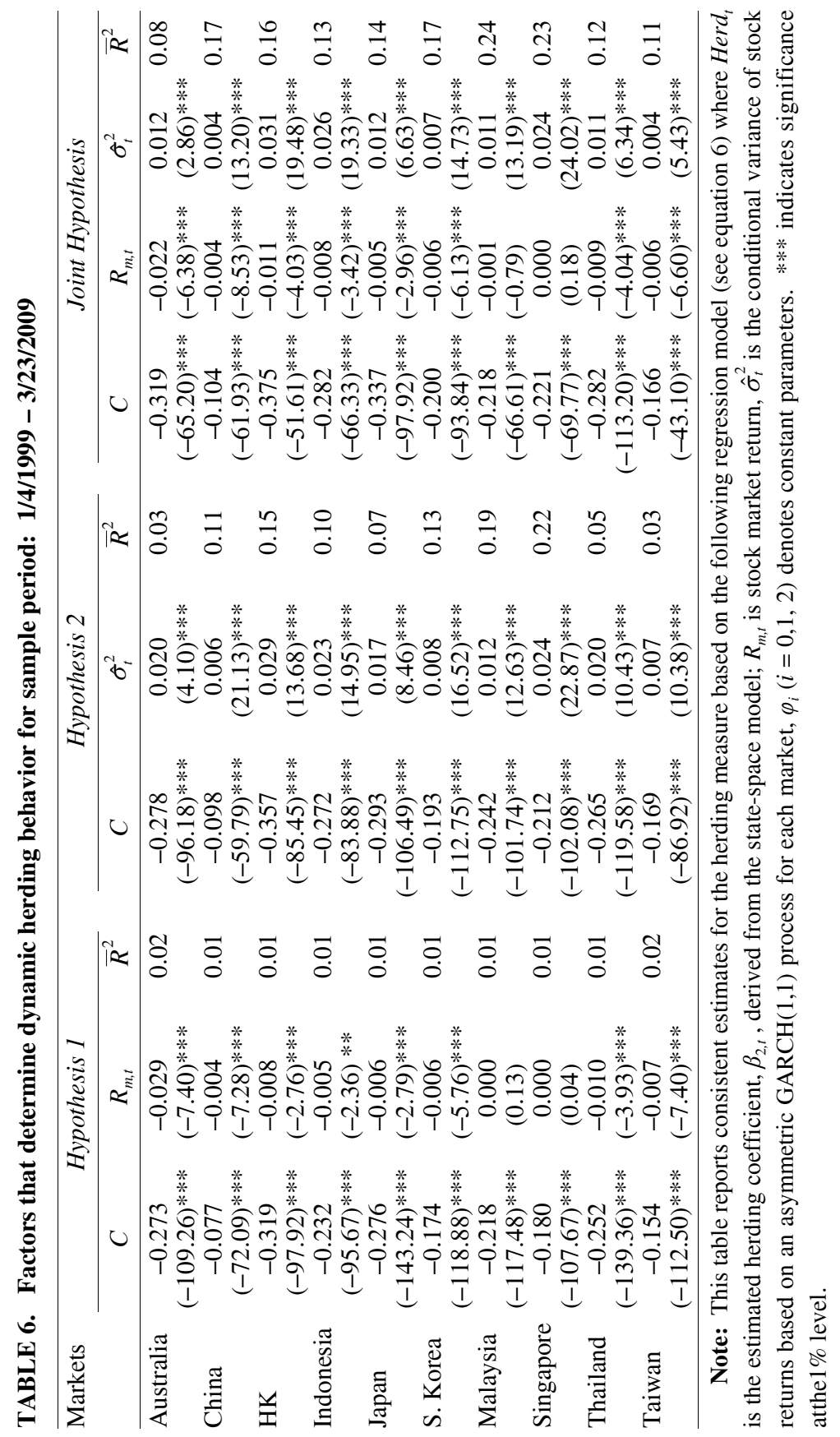


increases. ${ }^{13}$ However, as markets suffer losses, investors may be less likely to act in a coordinated manner, since they are unwilling to assume immediate losses and hesitate to sell their shares as stock prices fall (Statman,Thorley, and Vorkink, 2006). The evidence is in agreement with the earlier result that herding activity is more profound in a rising market than in a falling market. The finding is also consistent with the result of Duffee (2001), in that "aggregate trading volume tends to be higher on days when the stock market rises than when it falls."

Herding is positively correlated with stock return volatility, as all of the estimated slopes on the conditional variance variable are statistically significant at the $1 \%$ level. Since the herding measure itself has a negative value, a positive sign of the estimated coefficient means that the magnitude of the measured herding coefficient declines as conditional volatility increases. This is consistent with a market phenomenon that as uncertainty increases, investors who lack clear market signals and fundamentals are prone to act independently.

The evidence presented in table 6 suggests that investor reaction to the market state variables displays a complicated nonlinear behavior. Herding behavior is not only influenced by the occurrence of stressful events, but is also sensitive to prevailing market returns and conditional variance, among other factors. It appears that herding behavior is rather complex, and the evidence shows that it is consistent with a positive feedback trading process.

\section{B. Cross-market factors}

Evidence presented in the previous section focuses only on the domestic factors affecting herding dynamics. This section examines whether herding in a given market is affected by herding in other markets and global stock market volatility. The correlation in herding may be due to geographic proximity that produces close trading relation in the region, or to a similar cultural background with less transparency and less public information available, which would induce investors to form a correlated trading decision. The experience from the Asian crisis period indicates that herding behavior tends to display co-movements (Marais and Bates, 2006; Chiang, Jeon, and Li,2007). The evidence in table 5

13. The evidence here is not contradictory to the finding reported in table 3 , which examines how stock return dispersions react to extreme changes in market returns during rising and falling markets. The evidence in table 6 reveals the response of herding behavior to recent market conditions. 
also indicates that the markets in the Pacific Basin exhibit a high degree of correlation. This motivates the inclusion of a cross-market herding term in the model. The criterion for the selected cross-market factor is based on the simple correlation from table 5 , the visibility of the capital market, the region's dominance in trades, or the distance of the geographic location with respect to the local market.

The second cross-market factor is global market volatility, referred to as interdependence or spillovers from stock return volatility (Diebold and Yilmaz, 2009). Experience in recent financial crises indicates that it does not matter through which channel the volatility is transmitted (Pericoli and Sbracia, 2003). ${ }^{14}$ Whenever negative news develops in a given market, it will soon be learned by participants in other markets. As a result, international investors will reallocate their portfolios to hedge the shocks. $\mathrm{Ng}$ (2000) and Beirne et al. (2009) find evidence of significant stock-return volatility spillovers from the US market to many Pacific-Basin countries.

The impact of the volatility spillovers is assessed using the Chicago Board Options Exchange (CBOE) Volatility Index, commonly referred to as the VIX. The VIX is constructed using implied volatilities from options, and represents a forward-looking measure of the expected return volatility on the S\&P 500 index over the next 30 days. Whaley (2009) observes that the VIX spikes during periods of market turmoil, reflecting market conditions that if expected market volatility increases (decreases), stock prices fall (rise), and investors require a higher (lower) rate of return to compensate for bearing risk. Connolly, Stivers, and Sun (2005) find that the VIX can be considered a primary measure of perceived stock market risk or uncertainty. Tang and Yan (2010) identity that VIX as the most significant determinant of default risk among firm-level characteristics. Hakkio and Keeton (2009) further argue that the VIX can capture uncertainty arising from asset fundamentals or unexpected shifts in investor sentiment. Masih and Masih (2001) note that the financial information in the US market is considered to be most influential, and the VIX is also widely used in the literature (Beirne et al., 2009). Liu and Pan (1997) document that the US market affects volatility in Asian stock markets. Empirically, it is of interest to examine whether the implied volatility of the US stock

14. Pericoli and Sbracia (2003) provide a theoretical framework to highlight different channels for the international transmission of financial shocks. They show how crises that occur in one country can be transmitted across countries, without assuming ad hoc portfolio management rules or market imperfections. 
TABLE 7. Factors that determine dynamic herding behavior: Stock returns, conditional volatility, cross-market herding, and lagged VIX (sample period: $1 / 4 / 1999-3 / 23 / 2009$ )

\begin{tabular}{|c|c|c|c|c|c|c|}
\hline \multirow[b]{2}{*}{ Markets } & \multicolumn{6}{|c|}{ Domestic and cross-market independent variables } \\
\hline & $C$ & $R_{m, t}$ & $\hat{\sigma}_{t}^{2}$ & Cross $H_{E R D_{t}}$ & $V I X_{t-1}$ & $\bar{R}^{2}$ \\
\hline retrolis & $\begin{array}{c}-0.198 \\
(-22.18)^{* * *}\end{array}$ & $\begin{array}{l}-0.018 \\
(-6.00)^{* * *}\end{array}$ & $\begin{array}{l}0.008 \\
(2.70)^{* * * *}\end{array}$ & $\begin{array}{c}0.332 \\
(26.41)^{* * *}\end{array}$ & $\begin{array}{l}-0.001 \\
(-4.50)^{* *}\end{array}$ & 0.24 \\
\hline China & $\begin{array}{c}-0.045 \\
(-11.91)^{* * *}\end{array}$ & $\begin{array}{l}-0.004 \\
(-9.21)^{* * *}\end{array}$ & $\begin{array}{c}0.005 \\
(15.62)^{* * *}\end{array}$ & $\begin{array}{c}0.210 \\
(19.45)^{* * *}\end{array}$ & $\begin{array}{c}0.001 \\
(2.07) * *\end{array}$ & 0.29 \\
\hline Hong Kong & $\begin{array}{c}-0.193 \\
(-18.21)^{* * *}\end{array}$ & $\begin{array}{l}-0.007 \\
(-3.06)^{* * *}\end{array}$ & $\begin{array}{c}0.017 \\
(13.50)^{* * *}\end{array}$ & $\begin{array}{c}1.145 \\
(39.18)^{* * *}\end{array}$ & $\begin{array}{l}0.002 \\
(6.39)^{* * * *}\end{array}$ & 0.54 \\
\hline Indonesia & $\begin{array}{c}-0.133 \\
(-17.50)^{* * *}\end{array}$ & $\begin{array}{l}-0.004 \\
(-2.75)^{* * *}\end{array}$ & $\begin{array}{l}0.006 \\
(6.27)^{* * *}\end{array}$ & $\begin{array}{c}0.797 \\
(30.37)^{* * *}\end{array}$ & $\begin{array}{l}0.001 \\
(6.83)^{* * *}\end{array}$ & 0.38 \\
\hline Japan & $\begin{array}{c}-0.223 \\
(-32.86)^{* * *}\end{array}$ & $\begin{array}{l}-0.005 \\
(-3.08)^{* * *}\end{array}$ & $\begin{array}{c}0.018 \\
(14.04)^{* * *}\end{array}$ & $\begin{array}{c}0.613 \\
(19.25)^{* * * *}\end{array}$ & $\begin{array}{c}-0.002 \\
(-11.43)^{* * *}\end{array}$ & 0.28 \\
\hline South Korea & $\begin{array}{c}-0.247 \\
(-51.49) * * *\end{array}$ & $\begin{array}{l}-0.003 \\
(-4.23)^{* * *}\end{array}$ & $\begin{array}{c}0.002 \\
(0.89)\end{array}$ & $\begin{array}{l}0.060 \\
(6.46)^{* * *}\end{array}$ & $\begin{array}{c}0.004 \\
(24.30)^{* * *}\end{array}$ & 0.26 \\
\hline Malaysia & $\begin{array}{c}-0.130 \\
(-20.35)^{* * *}\end{array}$ & $\begin{array}{l}-0.001 \\
(-0.65)\end{array}$ & $\begin{array}{l}0.006 \\
(9.74)^{* * *}\end{array}$ & $\begin{array}{c}0.462 \\
(25.13)^{* * * *}\end{array}$ & $\begin{array}{c}0.001 \\
(2.39)^{* *}\end{array}$ & 0.40 \\
\hline Singapore & $\begin{array}{c}-0.141 \\
(-22.53)^{* * *}\end{array}$ & $\begin{array}{c}0.002 \\
(1.71)^{*}\end{array}$ & $\begin{array}{c}0.011 \\
(18.00)^{* * *}\end{array}$ & $\begin{array}{c}0.276 \\
(34.00)^{* * *}\end{array}$ & $\begin{array}{l}0.001 \\
(7.74)^{* * *}\end{array}$ & 0.54 \\
\hline Thailand & $\begin{array}{c}-0.233 \\
(-37.16)^{* * * *}\end{array}$ & $\begin{array}{l}-0.009 \\
(-4.10)^{* * *}\end{array}$ & $\begin{array}{l}0.004 \\
(2.35)^{* *}\end{array}$ & $\begin{array}{c}0.306 \\
(18.27)^{* * *}\end{array}$ & $\begin{array}{c}0.000 \\
(2.29)^{* *}\end{array}$ & 0.20 \\
\hline Taiwan & $\begin{array}{c}-0.129 \\
(-25.69)^{* * *}\end{array}$ & $\begin{array}{l}-0.006 \\
(-6.66)^{* * *}\end{array}$ & $\begin{array}{l}0.004 \\
(4.29)^{* * *}\end{array}$ & $\begin{array}{c}0.176 \\
(13.42)^{* * *}\end{array}$ & $\begin{array}{c}0.001 \\
(2.14)^{* *}\end{array}$ & 0.16 \\
\hline
\end{tabular}

Note: This table reports regression estimates of herding dynamics by using current stock returns $\left(R_{m, t}\right)$, conditional variance $\left(\hat{\sigma}_{t}^{2}\right)$, cross-market herding, and lagged global market volatility $(V I X)_{t-1}$. The estimated equation is given by:

Herd $_{t}=\varphi_{0}+\varphi_{1} R_{m, t}+\varphi_{2} \hat{\sigma}_{t}^{2}+\varphi_{3}(\text { Cross HERD })_{t}+\varphi_{4} V I X_{t-1}+\varepsilon_{t}$

$* * *, * *$, and $*$ indicate significance at the $1 \%, 5 \%$, and $10 \%$ levels, respectively.

market $(V I X)$ would have an effect on local stock volatility and herding behavior. For this reason, equation (6) is modified as:

$$
\begin{gathered}
\operatorname{Herd}_{t}=\varphi_{0}+\varphi_{1} R_{m, t}+\varphi_{2} \hat{\sigma}_{t}^{2}+ \\
\varphi_{3}(\text { Cross HERD })_{t}+\varphi_{4} \operatorname{VIX}_{t-1}+\varepsilon_{t}
\end{gathered}
$$




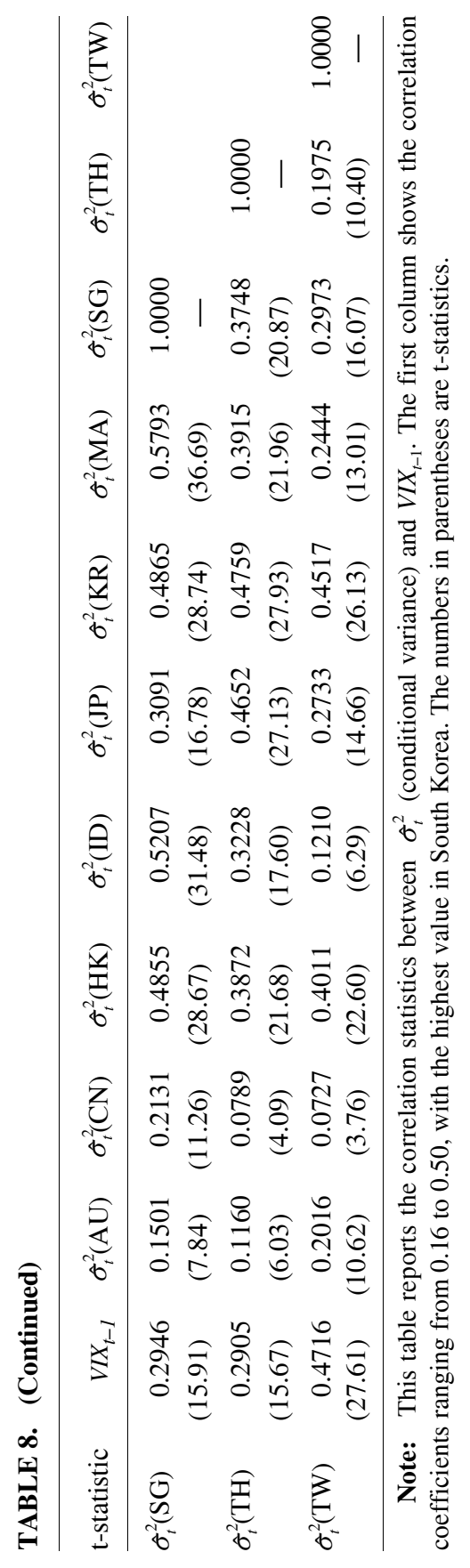


where the variable Cross $H E R D_{t}$ is the herding coefficient from the country that exhibits the greatest correlation with the herding coefficient that is the dependent variable.

Table 7 reports the coefficient estimates with cross-market herding (Cross HERD) and the lagged VIX as incremental variables. Including these additional variables significantly improves the explanatory power of the equation. The adjusted $R$-squared values in table 7 range from 0.16 to 0.54 , compared with values of 0.08 to 0.24 in the models in table 6 that did not include these additional control variables. However, the qualitative results of the market return and conditional stock-return variance remain significant, as we found earlier. Interestingly, the cross-market herding coefficient is positive and statistically significant at the $1 \%$ level for all markets. This finding suggests that investors' herding behavior in the Pacific Basin region exhibits co-movement. ${ }^{15}$

Turning to the coefficients on VIX $X_{t-1}$, with the exception of two advanced markets, Australia and Japan, all of the estimated coefficients in other Asian markets are positive and significant, suggesting that greater stock market volatility in S\&P 500 returns can influence herding behavior in the local market. The impact of the lagged VIX variable on herding is likely to carry an effect similar to that of local conditional volatility. ${ }^{16}$

Based on the evidence from the literature (Beirne et al., 2009), it is anticipated that $\hat{\sigma}_{t}^{2}$ and VIX $X_{t-1}$ may be positively correlated with each other due to either the cross-listing of shares (Howe and Madura, 1990; Chandar, Patro, and Yezegel, 2009), a contagion effect (King and Wadhwani, 1990), unobservable shocks (Dungey, Milunovich, and Thorp, 2010) or an asymmetrical impact of stock market co-movement across the return distribution (Beine, Cosma, and Vermeulen, 2010). Table 8 reports the correlation analysis between the lagged VIX $X_{t-1}$ and conditional variance for each market. As can be seen in the first column, the correlation coefficients range from 0.16 to 0.50 , with the highest value in South Korea. This is consistent with the finding in table 7 vis-à-vis the evidence in table 6 , where the coefficient on $\hat{\sigma}_{t}^{2}$ is

15. This evidence and the correlation analysis in table 5 are consistent with the results of Chiang and Zheng (2010), who find that stock return dispersions are correlated across international markets, but do not test for the interdependence of herding behavior across different markets

16. Using the current value of the VIX in the estimations, the results are comparable. Since the trading dates in Asian markets are about 12 hours ahead of the US market, using a lagged VIX is more relevant. 
insignificant when the $V I X_{\mathrm{t}-1}$ is included in the estimated equation. Although the evidence shows that $\sigma_{t}^{2}$ and $V I X_{t-1}$ to some extent are correlated, both $\hat{\sigma}_{t}^{2}$ and $V I X_{t-1}$ are still individually significant, meaning that each variable plays a role in explaining investors' behavior. In particular, $\hat{\sigma}_{t}^{2}$ represents local stock market risk, while VIX $X_{t-1}$ corresponds to global market risk. Both variables have a similar qualitative impact on herding.

\section{Implications of dynamic herding behavior}

The original herding model proposed by Chang, Cheng, and Khorana (2000) in Equation (2) posits that herding exists if stock return dispersions respond negatively to extreme market conditions as measured by the squared market return. The evidence from the state-space model clearly indicates that herding behavior is time-varying and sensitive to the prevailing market returns and conditional return volatility. This finding implies that investors' behavior when facing stressful market conditions is rather complex and the nonlinear reaction cannot be adequately captured by a simple term represented by $R_{m, t}^{2}$. To illustrate this point and simplify the analysis, just the domestic arguments of Equation (6) are incorporated in the original equation proposed by Chang, Cheng, and Khorana (2000). Doing so yields the following reduced-form equation:

$$
C S A D_{t}=b_{0}+b_{1}\left|R_{m, t}\right|+b_{2} R_{m, t}^{2}+b_{3} R_{m, t}^{3}+b_{4} \hat{\sigma}_{t}^{2} R_{m, t}^{2}+\varepsilon_{t}
$$

Comparing equation (8) with (2) indicates that two extra terms, $R_{m, t}^{3}$ and $\hat{\sigma}_{t}^{2} R_{m, t}^{2}$, are excluded from Chang, Cheng, and Khorana's (2000) original equation. In particular, $R_{m, t}^{3}$ can be viewed as a product term of $R_{m, t}^{2}$ and,$R_{m, t}$ representing the interaction of herding behavior with stock returns, and the product term $\hat{\sigma}_{t}^{2} R_{m, t}^{2}$ captures the interaction of herding with conditional variance. Equation (8) thus contains multiple elements of nonlinearity, reflecting various reactions of stock return dispersions to extreme market conditions.

Table 9 reports the estimates of the augmented equation. The incremental variables, $R_{m, t}^{3}$ and $R_{m, t}^{2} \cdot \hat{\sigma}_{t}^{2}$, are statistically significant, especially the $R_{m, t}^{2} \cdot \hat{\sigma}_{t}^{2}$ term. The F-statistics show that the joint test is rejected for all of the markets, suggesting that the state variables provide 


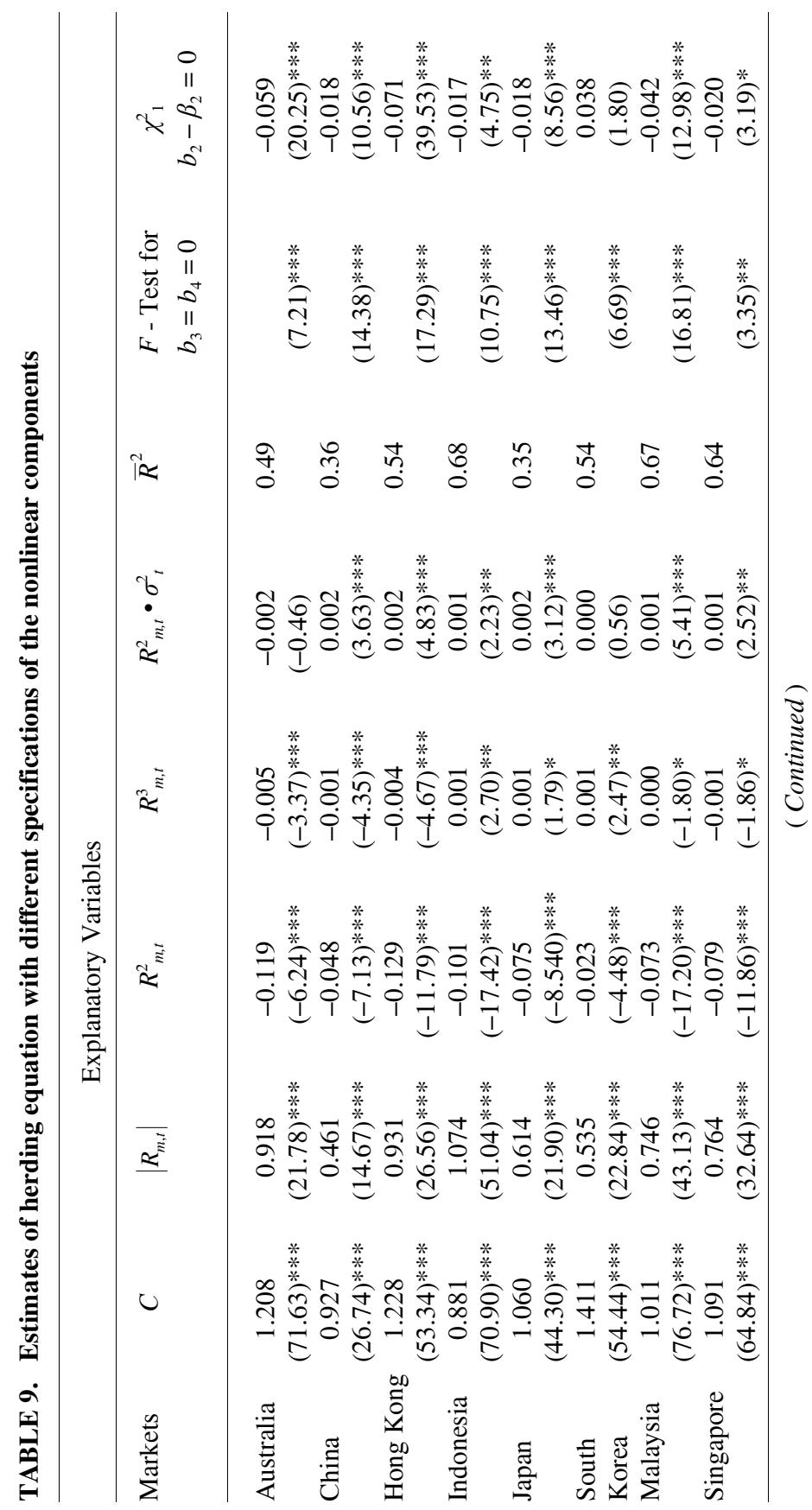




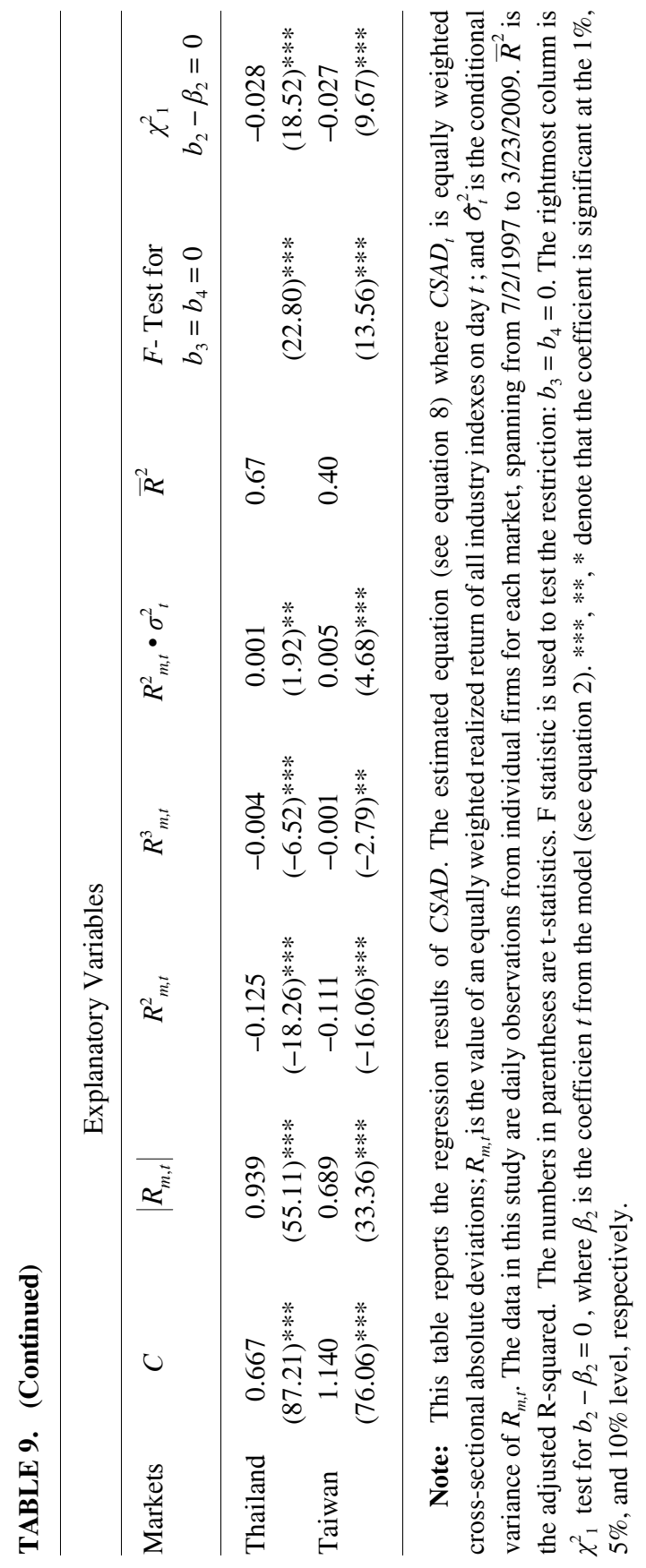


additional information to explain cross-sectional dispersion in returns.

Since the inclusion of the incremental variables is likely to change the magnitude of the standard measure of herding, it is appropriate to test whether the herding coefficient, $b_{2}$, of the augmented equation, is significantly different from the coefficient, $\beta_{2}$, in Chang, Cheng, and Khorana's (2000) original model. The Chi-squared statistics in table 9 clearly indicate that except for the South Korean market, the null hypothesis, $\left(b_{2}-\beta_{2}\right)=0$, is rejected with a negative sign. These results suggest that using the augmented equation in estimation contains richer information about market conditions and herding behavior. On average, the coefficient on the squared market return is more negative in the augmented specification than in the original one, suggesting that the original specification may be less able to detect the presence of herding.

\section{Summary and Conclusions}

This study examines investor herding behavior for ten Pacific-Basin markets: Australia, China, Hong Kong, Indonesia, Japan, Malaysia, South Korea, Singapore, Thailand, and Taiwan. To incorporate a global influence, we also include US data. By applying a constant coefficient regression model using daily data from July 2, 1997 through March 23, 2009 for individual firm stock returns, find significant evidence of herding in each national market, including the US. This result finding stands in contrast to the earlier evidence of no herding in advanced markets (Chang, Cheng, Khorana, 2000) or in Chinese markets (Demirer and Kutan, 2006).

The conventional estimation approach using the constant coefficient regression model provides information on the average relation between stock return dispersion and extreme movements in stock prices. Hence, the estimated results for detecting herding are essentially static in nature. We This study adopts a time-varying approach, by using a Kalman-filter-based model to estimate dynamic herding behavior. The evidence shows that herding behavior for the markets under investigation is indeed time-varying. The exception is the US market, which shows a positive sign, indicating a lack of herding.

This study also shows that dynamic herding behavior is significantly correlated with state variables such as current stock returns, conditional stock-return variance, and global stock volatility (VIX). The evidence suggests that an increase in stock returns leads to an increase in the 
herding measure, while a rise in local stock-return volatility or the VIX tends to reduce observed herding activity. We find that hHerding coefficients are positively correlated across markets, suggesting the interdependence of herding behavior in the Pacific-Basin region. An important implication emerging from this study is that investors' reaction to extreme market conditions is highly nonlinear. The evidence shows that herding behavior reacts not only to the occurrence of large swings in market prices, but also to the state of market return and volatility conditions. Omission of these state influences in an empirical model is likely to result in inaccurate inferences regarding herding.

Accepted by: Prof. H. Shefrin, Guest Editor, May 2013

Prof. P. Theodossiou, Editor-in-Chief, May 2013

\section{References}

Bekaert, G., and Wu, G. 2000. Asymmetric volatility and risk in equity markets. Review of Financial Studies 13, : 1-42.

Beine, M.; Cosma, A.; and Vermeulen, R. 2010. The dark side of global integration: increasing tail dependence. Journal of Banking and Finance 34, 184-192.

Beirne, K.; Caporale, G.M.; Schulze-Ghattas, M.; and Spagnolo, N. 2009. Volatility spillovers and contagion from mature to emerging stock markets. European Central Bank Working Paper, No. 1113, http://www.ecb.int/pub/pdf/scpwps/ecbwp1113.pdf.

Bikhchandani, S.; Hirshleifer, D.; and Welch, I. 1992. A theory of fads, fashion, custom, and cultural change as informational cascades. Journal of Political Economy 100, 992-1026.

Bikhchandani, S., and Sharma, S. 2001. Herd behaviour in financial markets. IMF Staff Papers 47(3), 279-310.

Boyer, B.; Kumagai, T.; and Yuan, K. 2006. How do crises spread? Evidence from accessible and inaccessible stock indices. Journal of Finance 61, 957-1003.

Brown, N.C.; Wei, K.D.; and Wermers, R. 2012, Analyst recommendations, mutual fund herding, and overreaction in stock prices, working paper, University of Maryland.

Butler, K. C., and Joaquin, D.C., 2002. Are the gains from international portfolio diversification exaggerated? The influence of downside risk in bear markets. Journal of International Money and Finance 21, 981-1011.

Chang, E.C.; Cheng, J.W.; and Khorana, A. 2000. An examination of herd behavior in equity markets: An international perspective. Journal of Banking and Finance 24, 1651-1679. 
Chandar, N.; Patro, D.K.; and Yezegel, A. 2009. Crises, contagion and cross-listings, . Journal of Banking and Finance 33, 1709-1729.

Chiang, T. C., and Zheng, D., 2010. An empirical analysis of herd behavior in global stock markets. Journal of Banking and Finance 34, 1911-1921.

Chiang, T. C.; Jeon, B.N.; and Li, H., 2007. Dynamic correlation analysis of financial contagion: Evidence from Asian markets. Journal of International Money and Finance 26, 1206-1228.

Chiang, T. C.; Chen, C.W.S.; and So, M.K.P. 2007. Asymmetric return and volatility responses to composite news from stock markets. Multinational Finance Journal 11, 179-210.

Christie, W.G., and Huang, R.D., 1995. Following the pied piper: Do individual returns herd around the market? Financial Analysts Journal 51, 31-37.

Connolly, R. A.; Stivers, C.T.; and Sun, L. 2005. Stock market uncertainty and the stock-bond return relation. Journal of Financial and Quantitative Analysis 40, 161-194.

Corsetti, G.; Pericoli, M.; and Sbracia, M., 2005. Some contagion, some interdependence: More pitfalls in tests of financial contagion. Journal of International Money and Finance 24, 1177-1199.

DeLong, J. B.; Shleifer, A.; Summers, L.; and Waldmann, R. 1990. Positive feedback investment strategies and destabilizing rational speculation. Journal of Finance 45, 374-397.

Demirer, R., and Kutan, A.M., 2006. Does herding behavior exist in Chinese stock markets? Journal of International Financial Markets, Institutions and Money 16 (2), 123-142.

Diebold, F.X., and Yilmaz, K. 2009. Measuring financial asset return and volatility spillovers, with application to global equity markets. Economic Journal 119, 158-171.

Duffee, G. R., 2001. Asymmetric cross-sectional dispersion in stock returns : Evideceanimplications.WorkingPaper,University of California--Berkeley www.haas.berkeley.edu/ duffee.

Dungey, M.; Milunovich, G.; and Thorp, S. 2010. Unobservable shocks as carriers of contagion. Journal of Banking and Finance 34: 1006-1021.

Forbes, K., and Rigobon, R. 2002. No contagion, only interdependence: Measuring stock market comovements. Journal of Finance 57, 2223-2261.

Garbade, K., and Wachtel, P. 1978, Time variation in the relationship between inflation and interest rates. Journal of Monetary Economics 4, 755-765.

Gleason, K.C.; Mathur, I.; and Peterson, M.A. 2004. Analysis of intraday herding behavior among the sector ETFs. Journal of Empirical Finance 11, 681-694.

Goldberg, C.S., and Delgado, F. 2001. A Financial integration of emerging markets: An analysis of Latin America versus South Asia using individual stocks. Multinational Finance Journal, 5, 259-301.

Grinblatt, M.; Titman, S.; and Wermers, R. 1995. Momentum investment strategies, portfolio performance, and herding: A study of mutual fund 
behavior. American Economic Review 85, 1088-1105.

Hakkio, C., and Keeton, W.R. 2009. Financial stress: what is it, how can it be measured, and why does it matter? Economic Review, Federal Reserve Bank of Kansas City. 2, 5-50.

Hamilton, J.D. 1994. Time Series Analysis. Princeton: Princeton University Press, Princeton, NJ.

Harvey, A.C. 1990. Forecasting, Structural Time Series Models and the Kalman Filter. Cambridge: Cambridge University Press, Cambridge, UK.

Hirshleifer, D.; Subrahmanyam, A.; and Titman, S., 1994. Security analysis and trading patterns when some investors receive information before others. Journal of Finance 49, 1665-1698.

Howe, S., and Madura J. 1990. The impact of international listings on risk: implications for capital market integration. Journal of Banking and Finance $14,1133-42$.

Hwang, S., and Salmon, M., 2004, Market stress and herding. Journal of Empirical Finance 11, 585-616.

Kalman, R.E. 1960. A new approach to linear filtering and prediction problem. Journal of Basic Engineering, Transactions ASMA. Series D 82, 35-45.

King, M., and Wadhwani, S. 1990. Transmission of volatility between stock markets. Review of Financial Studies, 3(1), 5-33.

Liu, Y. A., and Pan, M. 1997. Mean and volatility spillover effects in the U.S. and Pacific-Basin stock markets, . Multinational Finance Journal, 1, 47-62.

Maddala, G.S., and Kim, I. 2002, Unit Roots, Cointegration, and Structural Change. New York: Cambridge University Press. New York, NY.

Marais, E., and Bates, S., 2006. An empirical study to identify shift contagion during the Asian crisis. Journal of International Financial Markets, Institutions and Money 16 (5), 468-479.

Masih, R., and Masih, A.M.M., 2001. Long and short term dynamic causal transmission amongst international stock markets. Journal of International Money and Finance 20, 563-587.

McQueen, G.; Pinegar, M.; and Thorley, S. 1996. Delayed reaction to good news and the cross-autocorrelation of portfolio returns. Journal of Finance 51, 889-919.

Newey, W., and West, K. 1987. A simple, positive semi-definite, heteroskedasticity and autocorrelation consistent covariance matrix. Econometrica 55, 703-708.

Nofsinger, J., and Sias, R. 1999. Herding and feedback trading by institutional and individual investors. Journal of Finance 54, 2263-2295.

$\mathrm{Ng}$, A. 2000, Volatility spillover effects from Japan and the US to the Pacific-Basin. Journal of International Money and Finance 19, 207-233.

Pericoli, M., and Sbracia, M. 2003. A primer on financial contagion. Journal of Economic Surveys 17(4), 571-608. DOI: 10.1111/1467-6419.00205.

Sentana, E., and Wadhwani, S. 1992. Feedback traders and stock return autocorrelations: evidence from a century of daily data. Economic Journal 
$102,415-435$.

Shiller, R.J. 2005. Irrational Exuberance, Second edition. Princeton: Princeton University Press, Princeton, NJ.

Statman, M., Thorley, S., and Vorkink, K. 2006. Investor overconfidence and trading volume. Review of Financial Studies 19(4), 1531-1565.

Sy, A., 2007. Malaysia: An Islamic capital market hub. IMF Survey Magazine: Country \& Regions, September 18.

http://www.imf.org/external/pubs/ft/survey/so/2007/CAR0919A.htm

Tan, L., Chiang, T.C., Mason, J., and Nelling, E. 2008. Herding behavior in Chinese stock markets: An examination of A and B shares. Pacific-Basin Finance Journal 16, 61-77.

Tang, D.Y., and Yan, H. 2010. Market conditions, default risk and credit spreads. Journal of Banking and Finance 34, 743-753.

Tsay, R.S., 2005. Analysis of Financial Time Series, Second edition, . Hoboken: Wiley Series. Hoboken, NJ.

Wermers, R. 1999. Mutual fund herding and the impact on stock prices. Journal of Finance 54, 581-622.

Whaley, R. E. 2009. Understanding the VIX. Journal of Portfolio Management $35,98-105$.

Yu, I-W.; Fung, K-P.; and Tam, C-S. 2010. Assessing financial market integration in Asia - Equity markets, Journal of Banking and Finance 34, 2874-2885.

Zhou, R., and Lai, R., 2009. Herding and information based trading. Journal of Empirical Finance 16, 388-393. 